\title{
Pengaruh Keterampilan Berbahasa Inggris Penjual Bunga Tabur Terhadap Minat Beli Wisatawan Mancanegara
}

\author{
${ }^{1}$ Lu'lu U1 Maknunah, ${ }^{2}$ Nuryanti \\ ${ }^{1,2}$ Fakultas Ilmu Sosial dan Ilmu Politik, Universitas Islam Balitar \\ Jl. Majapahit No. 2 - 4, Blitar 66139, Indonesia
}

Email: 1'uul.unisba@gmail.com, ${ }^{2}$ nury41954@gmail.com

\begin{tabular}{l} 
Tersedia Online di \\
\hline $\begin{array}{l}\text { http://www.jurnal.unublitar.ac.id/i } \\
\text { ndex.php/briliant }\end{array}$ \\
\hline Sejarah Artikel \\
\hline Diterima pada 17 September 2020 \\
Disetujui pada 13 November 2020 \\
Dipublikasikan pada 28 Februari \\
2021 \\
Hal. 33-40 \\
\hline
\end{tabular}

\section{Kata Kunci:}

Pengaruh, Keterampilan,

Berbahasa, Minat, Beli

\section{DOI:}

http://dx.doi.org/10.28926/briliant. v3i4.551

\begin{abstract}
Abstrak: Penjual bunga tabur di makam Bung Karno Kota Blitar harus menggunakan Bahasa Inggris ketika calon pembelinya wisatawan mancanegara. Tata bahasa yang mereka gunakan masih belum beraturan dan kosakatanya kurang. Padahal jika mereka dapat menawarkan bunga tabur dengan tata bahasa yang baik maka wisatawan mancanegara akan tertarik membeli. Tujuan penelitian ini adalah melihat pengaruh kemampuan bahasa Inggris penjual bunga tabur pada minat beli wisatawan asing. Pendekatan yang digunakan pada penelitia yang dilakukan adalah dengan metode survei melalui pendekatan kuantitatif dan analisis statistik regresi. Hasil akhir yang diperoleh adalah tidak adanya pengaruh berbahasa Inggris terhadap minat beli wisatawan mancanegara, dibuktikan dari signifikansi uji $\mathrm{T}$ $0,061>0,05$.
\end{abstract}

\section{PENDAHULUAN}

Makam Bung Karno merupakan salah satu potensi wisata sejarah terbesar di Kota Blitar. Dari data Dinas Pariwisata dan Kebudayaan Kota Blitar menunjukkan sebanyak 3.167.480 pewisata yang datang ke tempat wisata Makam Bung Karno pada tahun 2019. Orang yang sedang melakukan perjalanan dengan tujuan berekreasi pada satu waktu dan di sebuah tempat tertentu merupakan pengertian dari wisatawan (Judisseno, 2017:14). Wisatawan dapat dibagi menjadi 2 jenis wisatawan yang dilihat berdasarkan daerah asalnya diantaranya wisatawan mancanegara dan domestik. Wisatawan mancanegara adalah orang yang bermalam setidaknya satu malam di sebuah penginapan suatu negara dan wisatawan domestik adalah orang yang setidaknya menginap satu malam di negaranya sendiri (Bafadhal, 2018:6).

Banyaknya pewisata yang datang ke tempat wisata Makam Bung Karno membuat tempat wisata tersebut diserbu oleh penjual bunga tabur untuk ditaburkan di atas makam Bung Karno. Perbedaan wisatawan mancanegara dan wisatawan domestik terletak pada komunikasi antara penjual bunga tabur dengan wisatawan dalam proses jual beli. Penjual bunga tabur tentu harus menggunakan Bahasa Inggris dalam proses jual beli ketika calon pembelinya adalah wisatawan 
mancanegara. Bahasa Inggris adalah Bahasa Internasional biasanya dipakai untuk komunikasi antara dua orang yang berbeda Bahasa Ibunya. Terdapat kemungkinan keterampilan berbahasa Inggris penjual bunga di tempat wisata Makam Bung Karno mempengaruhi minat beli wisatawan mancanegara.

Kemungkinan tersebut diperkuat dengan pendapat Febryan (2010:240) bahwa mendapatkan dan menumbuhkan minat untuk membeli merupakan tugas seorang penjual. Minat untuk membeli hanya dapat diperoleh apabila sang penjual sukses melaksanakan pendekatan kepada calon pembelinya. Pendekatan yang dimaksud tentu berkaitan dengan komunikasi antara penjual dengan calon pembelinya. Pada umumnya penjual bunga tabur di Makam Bung Karno dalam menawarkan bunganya kepada wisatawan mancanegara belum menguasai tata bahasa dan kosakata bahasa Inggris. Tata bahasa yang mereka gunakan masih belum beraturan dan kosakatanya masih kurang. Padahal kemungkinan bila mereka dapat menawarkan bunga dengan tata bahasa yang baik para wisatawan mancanegara akan tertarik membeli bunga.

Dari permasalahan yang telah dipaparkan diperlukan penelitian yang mendalam, sehingga penelitian ini mengangkat tentang Pengaruh Keterampilan Berbahasa Inggris Penjual Bunga Tabur Terhadap Minat Beli Wisatawan Mancanegara (Studi Kasus Di Tempat Wisata Makam Bung Karno Kota Blitar) dengan kerangka pemikiran yang divisualkan pada gambar 1 berikut ini.

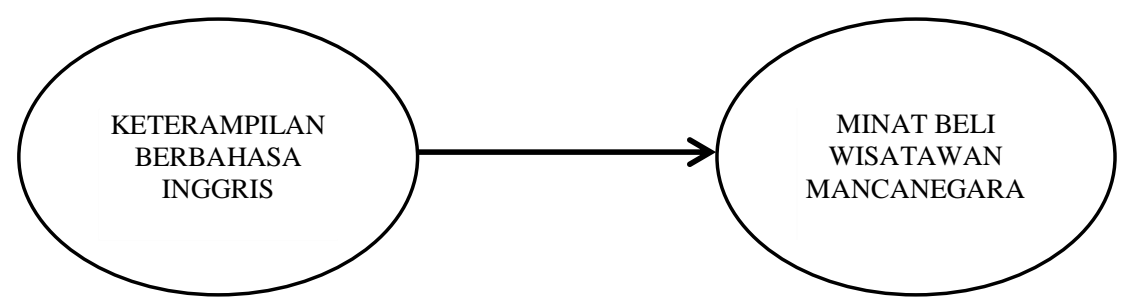

Gambar 1. Kerangka Pemikiran

Dalam kerangka pemikiran diatas, ketrampilan berbahasa Inggris merupakan variabel bebas (X). Terdapat dua garis besar keterampilan dalam berbahasa (termasuk ke dalamnya Bahasa Inggris) yaitu yang pertama keterampilan berbahasa lisan yang terdiri atas keterampilan berbicara dan keterampilan menyimak. Kedua adalah keterampilan berbahasa tulis diantaranya keterampilan menulis dan keterampilan membaca. Indikator keterampilan berbahasa di sini adalah penguasaan tata bahasa (grammar) dan kosakata (vocabulary). Seseorang dikatakan terampil dalam berbahasa ketika orang tersebut mampu berkomunikasi baik secara lisan atau tulisan dengan lawan bicaranya dengan khazanah kosakata yang cukup dan tata Bahasa yang baik dan benar (Zaim, 2016:3). Sedangkan minat beli wisatawan mancanegara merupakan variabel terikat (Y).

Berdasarkan kerangka pemikiran (pada gambar 1), dapat ditarik hipotesa pada penelitian yang akan dilakukan diantaranya:

Ho: Diduga tidak ada pengaruh keterampilan berbahasa Inggris penjual bunga tabur terhadap minat beli wisatawan mancanegara di tempat wisata Makam Bung Karno kota Blitar. 
Ha: Diduga ada pengaruh keterampilan berbahasa Inggris penjual bunga tabur terhadap minat beli wisatawan mancanegara di tempat wisata Makam Bung Karno kota Blitar.

\section{METODE}

Metode yang diterapkan dalam penelitian yang akan dilakukan menggunakan metode kuantitatif. Menurut Muharto dan Ambarita (2016:91), penelitian kuantitatif memiliki tujuan untuk uji terhadap hipotesa yang telah dirumuskan, sehingga pada penelitian kuantitatif terdapat beberapa variabel penelitian. Pada penelitian ini digunakan analisis statistik yaitu analisis regresi yang bertujuan untuk uji pengaruh terhadap dua atau lebih variabel. Sedangkan untuk metode penelitian pada kasus yang akan diteliti digunakan metode survei. Menurut Sudaryo, dkk (2019:65), penelitian survei merupakan penilitian yang menggunakan sample dari sebuah populasi dan digunakan kuesioner untuk alat pengumpul data penelitian.

Ada dua variabel yang digunakan, diantaranya variabel bebas dan variabel terikat. Disebutkan bahwa (Bungin, 2017:82), variabel bebas (X) yaitu sebuah variabel yang memiliki pengaruh terhadap variabel terikat. Sedangkan variabel terikat merupakan suatu variabel yang dipengaruhi akibat variabel bebas (Y). Pada kasus ini, variabel bebas adalah keterampilan berbahasa Inggris dan variabel terikatnya adalah minat beli wisatawan mancanegara. Populasi pada penelitian ini adalah rata-rata wisatawan mancanegara yang berkunjung ke Makam Bung Karno dalam kurun waktu satu bulan yaitu sebanyak 125. Sebanyak 56 sampel yang akan dipergunakan, dengan menghasiklan nilai berdasarkan rumus Slovin dengan kelonggaran ketidaktelitian sebesar $10 \%$. Untuk sampling digunakan teknik sampling aksidental.

Sedangkan untuk pengumpulan data digunakan teknik pengumpulan data dokumentasi, kuesioner dan studi kepustakaan. Peneliti akan menyebarkan kuesioner dengan bantuan google formulir dan akan disebarkan melalui social media. Hasil kuesioner akan diuji ke dalam beberapa uji statistika dengan bantuan aplikasi SPSS. Beberapa uji yang diterapkan diantaranya uji instrument, uji asumsi klasik dan uji regresi. Uji instrument dibagi lagi ke dalam uji validitas dan uji reliabilitas. Kemudian pada uji asumsi klasik juga menggunakan dua uji yaitu uji normalitas dan uji heteroskedastisitas. Sedangkan untuk uji regresi digunakan uji t.

\section{HASIL}

\section{Uji Instrument}

\section{Uji Validitas}

Menurut (Endra, 2017:132) uji validitas adalah kelayakan dari sebuah instrument penelitian untuk bisa melakukan pengukuran terhadap apa yang seharusnya diukur serta sejauh mana instrument penelitian tersebut dapat menjalankan fungsi pengukurannya. Hasil uji validitas pada instrument keterampilan berbahasa Inggris sebagai variable bebas dan minat beli wisatawan mancanegara sebagai varibel terikat, dapat dilihat pada Tabel 1. Menurut Gunawan (2020:93), data dikatakan valid ketika nilai signifikansi (sig.) adalah 
kurang dari 0,05 dan apabila hasil sig.nya lebih dari 0,05 sehingga dikatakan tidak valid.

Tabel 1. Hasil Uji Validasi

\begin{tabular}{|c|c|c|}
\hline Variabel & Nilai Sig. & Keterangan \\
\hline X1.1 & 0,000 & Valid \\
\hline X1.2 & 0,000 & Valid \\
\hline X1.3 & 0,000 & Valid \\
\hline X1.4 & 0,000 & Valid \\
\hline X1.5 & 0,000 & Valid \\
\hline Y1.1 & 0,000 & Valid \\
\hline Y1.2 & 0,000 & Valid \\
\hline Y1.3 & 0,000 & Valid \\
\hline Y1.4 & 0,000 & Valid \\
\hline Y1.5 & 0,000 & Valid \\
\hline
\end{tabular}

Dari Tabel 1, dapat diketahui bahwa baik variabel bebas ataupun variabel terikat, seluruhnya sudah terdapat instrument penelitian dengan keterangan valid. Hal tersebut terlihat dari nilai Sig. masing-masing instrument penelitian bernilai 0,000. Dari X1.1 sampai Y1.5 memiliki nilai signifikan 0,000.

\section{Uji Reliabilitas}

Selanjutnya dilakukan pengujian reliabilitas, yang dimana uji ini dilakukan untuk memastikan sejauh mana instrument penelitian dapat diandalkan untuk mengukur suatu objek penelitian (Purnama, 2015:137). Jika hasil cronbach's alpha lebih dari 0,6 maka instrument dapat memenuhui unsur reliable (Widayat, 2018: 141). Hasil reliabilitas pada instrument penelitian terdapat pada Tabel 2. Tabel tersebut menunjukkan jika data telah reliable. Variabel bebas yaitu variabel $\mathrm{X}$ atau variabel keterampilan berbahasa Inggris memiliki nilai cronbach's alpha 0,786 dan variabel terikat yaitu variabel $Y$ atau variabel minat beli memiliki nilai cronbach's alpha 0,768. Kedua nilai tersebut sudah lebih dari 0,6, sehingga instrument penelitian memiliki kehandalan dalam mengukur objek penelitian.

Tabel 2. Hasil Reliabilitas

\begin{tabular}{|c|c|}
\hline Variabel & Cronbach's Alpha \\
\hline $\mathrm{X}$ & 0,786 \\
\hline $\mathrm{Y}$ & 0,768 \\
\hline
\end{tabular}

\section{Uji Asumsi Klasik}

\section{Uji Normalitas}

Pada uji ini, bertujuan agar diketahui apakah sebuah data telah memiliki distribusi data yang mengikuti maupun mendekati distribusi normal (Siregar dan Winita, 2017:113). Pada penelitian yang dilakukukan digunakan uji normalitas pada nilai residual terstandarisasi (unstandardized residual). Hal ini sejalan dengan apa yang juga dipaparkan oleh Riyanto dan Hatmawan (2020:153) bahwa langkah dalam menguji normalitas suatu data salah satunya adalah dengan membuat data nilai residual terstandarisasi terlebih dahulu dan data yang telah 
dilakukan uji Kolmogorov-Smirnov yang memiliki distribusi normal apabila nilai signifikannya adalah lebih dari sama dengan 0,05 . Tabel 3 berikut ini menunjukkan hasil uji normalitas dari penelitian ini.

Tabel 3. Hasil Uji Normalitas

One-Sample Kolmogorov-Smirnov Test

\begin{tabular}{|c|c|c|}
\hline & & $\begin{array}{l}\text { Unstandardized } \\
\text { Residual }\end{array}$ \\
\hline $\mathrm{N}$ & & \\
\hline Normal Parameters ${ }^{\mathrm{a}, \mathrm{b}}$ & Mean & ,0000000 \\
\hline & Std. Deviation & 3,47625768 \\
\hline Most Extreme Differences & Absolute & 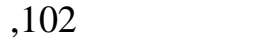 \\
\hline & Positive &, 075 \\
\hline & Negative &,- 102 \\
\hline Kolmogorov-Smirnov Z & & ,764 \\
\hline Asymp. Sig. (2-tailed) & & 604 \\
\hline
\end{tabular}

a. Test distribution is Normal.

b. Calculated from data.

Dari hasil uji normalitas menunjukkan bahwa data hasil penyebaran kuesioner telah terdistribusi normal. Ini telihat dari nilai Asymp. Sig. (2-tailed) mendapatkan hasil 0,604. Hasil tersebut sudah lebih dari sama dengan 0,05, maka data yang digunakan telah mengikuti ataupun mendekati distribusi normal.

\section{Uji Heteroskedastisitas}

Uji ini memiliki tujuan yakni agar dapat diketahui model regresi yang digunakan apakah terdapat varian residual yang tidak sama dari sebuah pengamatan terhadap pengamatan lainnya (Rukajat, 2018:16). Penelitian ini digunakan uji Glejser dan hasil dari pengujian heteroskedastisitas dapat diketahui pada Tabel 4. Berdasarkan tabel tersebut, dapat disumpulkan bahwa data yang ada tidak memiliki masalah heteroskedastisitas. Karena telah sesuai dengan apa yang dipaparkan oleh Riyanto dan Hatmawan (2020:209), bahwa semua koefisien parameter untuk semua variabel penelitian dikatakan tidak memiliki masalah heteroskedastisitas ketika nilai signifikannya adalah lebih dari 0,05.

Tabel 4. Hasil Uji Heteroskedastisitas

Coefficients $^{\mathbf{a}}$

\begin{tabular}{|c|c|c|c|c|c|}
\hline \multirow[t]{2}{*}{ Model } & \multicolumn{2}{|c|}{$\begin{array}{c}\text { Unstandardized } \\
\text { Coefficients }\end{array}$} & \multirow{2}{*}{ 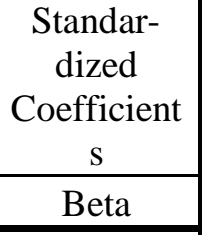 } & \multirow[b]{2}{*}{$\mathrm{t}$} & \multirow[b]{2}{*}{ Sig. } \\
\hline & $\mathrm{B}$ & Std. Error & & & \\
\hline $\begin{array}{ll}1 & \text { (Constant) } \\
& \text { KETERAMPILAN } \\
\text { BERBAHASA } \\
\text { INGGRIS }\end{array}$ & $\begin{array}{l}3,050 \\
-, 015\end{array}$ & ,104 ${ }^{1,781}$ &,- 019 & $\begin{array}{l}1,713 \\
-, 140\end{array}$ & $\begin{array}{l}, 093 \\
, 889\end{array}$ \\
\hline
\end{tabular}

a. Dependent Variable: Abs_Res

BRILIANT: Jurnal Riset dan Konseptual

Volume 6 Nomor 1, Februari 2021 


\section{Uji Regresi (Uji T)}

Uji regresi atau uji $\mathrm{T}$ dalam penelitian ini adalah uji yang digunakan agar diketahui pengaruh dari variabel bebas, yaitu variabel keterampilan berbahasa Inggris terhadap variabel terikat yaitu variabel minat beli wisatawan mancanegara. Sayidah (2018:122) menjelaskan bahwa tujuan dari uji regresi yaitu agar mengetahui pengaruh variabel $\mathrm{X}$ dengan variabel $\mathrm{Y}$. Pengaruh tersebut dapat berupa pengaruh parsial dengan menggunakan uji $\mathrm{T}$ ketika variabel bebas yaitu variabel X hanya ada satu variabel saja. Hasil uji T ini ditunjukkan pada Tabel 5.

Tabel 5. Hasil Uji T

Coefficients $^{\mathrm{a}}$

\begin{tabular}{|c|c|c|c|c|c|c|}
\hline \multirow{2}{*}{\multicolumn{2}{|c|}{ Model }} & \multicolumn{2}{|c|}{$\begin{array}{l}\text { Unstandardized } \\
\text { Coefficients }\end{array}$} & \multirow{2}{*}{$\begin{array}{c}\begin{array}{c}\text { Standar- } \\
\text { dized } \\
\text { Coefficients }\end{array} \\
\text { Beta } \\
\end{array}$} & \multirow[b]{2}{*}{$\mathrm{t}$} & \multirow[b]{2}{*}{ Sig. } \\
\hline & & $\mathrm{B}$ & Std. Error & & & \\
\hline & $\begin{array}{l}\text { (Constant) } \\
\text { KETERAMPILAN } \\
\text { BERBAHASA } \\
\text { INGGRIS }\end{array}$ & ${ }^{11,276}$ &, $178^{3,065}$ & ,252 & $\begin{array}{l}3,679 \\
1,914\end{array}$ & $\begin{array}{l}, 001 \\
, 061\end{array}$ \\
\hline
\end{tabular}

a. Dependent Variable: MINAT BELI

Dari hasil uji $\mathrm{T}$ yang telah dilakukan, dapat dilihat nilai signifikansinya adalah 0,061. Menurut Gani dan Amalia (2015:144), jika taraf nyata alpha $(0,05)$ kurang dari tingkat signifikansi maka Ho dapat diterima. Maka disimpulkan bahwa Ho diterima, artinya tidak terdapat pengaruh keterampilan Bahasa Inggris penjual bunga tabur di Makam Bung Karno terhadap minat beli wisatawan mancanegara.

\section{PEMBAHASAN}

Keterampilan berbahasa Inggris merupakan salah satu strategi penjual dalam memasarkan produk khusunya pada wisatawan mancanegara. Penjual akan lebih leluasa dalam menawarkan dan konsumen dipengaruhi agar dapat melakukan pembelian terhadap produk yang dijual. Apabila seorang penjual memiliki keterampilan bahasa asing yang baik dan benar maka akan mudah dalam berkomunikasi dengan wisatawan asing. Hal ini sesuai dengan teori dari Kotler dan Keller (2016:580), dikatakan bahwa komunikasi pemasaran merupakan sarana perusahaan yang terdapat upaya untuk untuk memebrikan informasi, merayu, dan konsumen diingatkan baik langsung maupun tidak langsung terkait produk atau merek yang dijual.

Hasil temuan pada penelitian ini menunjukkan bahwa keterampilan berbahasa Inggris penjual bunga tabur baik dilihat dari sisi tata bahasa, kosakata, pemahaman, kelancaran dan pelafalan masih tergolong kurang. Keterampilan berbahasa Inggris penjual bunga tabur di kawasan wisata Makam Bung Karno tidak memiliki pengaruh positif kepada minat konsumen untuk membeli. Hal ini dikarenakan umumya tujuan wisatawan asing datang ke makam Bung Karno dikarenakan untuk wisata bukan untuk nyekar dan tebar bunga atau doa/tahlil 
seperti tradisi budaya di Indonesia. Umumnya mereka tidak tau arti dari kebiasaan nyekar tersebut.

Nyekar merupakan istilah dari kata Sekar yang memiliki arti kembang atau bunga. Nyekar juga diartikan sebagai sebuah tradisi ziarah kubur dimana sang peziarah membawa bunga lalu peziarah menaburkan bunga tersebut di atas makam nenek moyang/ leluhur. Tradisi Ziarah ke makam merupakan satu dari beberapa tradisi yang masih bertahan serta tumbuh di dalam masyarakat Jawa (Kastolani dan Yusof, 2016). Tradisi Ziarahpun juga berkembang di Makam Bung Karno dengan cara nyekar/menabur bunga di atas makam Bung Karno. Ziarah Kubur mengandung hikmah sebagai peringatan terhadap sesorang yang masih hidup bahwa akan terjadi kematian. Ada suatu masa yang telah ditentukan akan datang ajal sesuai dengan kodrat yang telah ditetapkan, jika semua makhluk yang hidup akan mengalami kematian.

\section{KESIMPULAN}

Kesimpulan yang dapat ditarik dari penelitian ini adalah bahwa tidak ada pengaruh dari keterampilan berbahasa Inggris terhadap minat beli para wisatawan mancanegara di Makam Bung Karno Kota Blitar. Hal tersebut diketahui dari nilai sig. pada uji $\mathrm{T}$ yang nilainya lebih dari alpha $(0,05)$, yaitu 0,061 . Faktor yang menyebabkan tidak adanya pengaruh keterampilan berbahasa Inggris terhadap minat beli para wisatawan mancanegara di Makam Bung Karno Kota Blitar adalah budaya tabur bunga di Makam yang memang tidak ada dalam kebudayaan wisatawan mancanegara.

\section{SARAN}

Saran yang dapat diberikan bagi pengelola makam Bung Karno adalah adanya kerjasama yang baik dengan para penjual bunga tabur dan perlunya dilakukan pelatihan berbahasa Inggris untuk para penjual bunga tabur di Makam Bung Karno Kota Blitar, terutama terkait dengan kosakata bahasa Inggris mengenai budaya tabur bunga di Indonesia.

\section{DAFTAR RUJUKAN}

Bafadhal, A.S. (2018). Perencanaan Bisnis Pariwisata: Pendekatan Lean Planning. Malang. UB Press.

Bungin, B. (2017). Metodologi Penelitian Kuantitatif. Cetakan ke-9. Jakarta: Kencana.

Endra, F. (2017). Pedoman Metodologi Penelitian: (Statistika Praktis). Sidoarjo: Zifatama Jawara.

Febriani, N. S., dan Dewi, W. W. A. (2018). Teori dan Praktis: Riset Komunikasi Pemasaran Terpadu. Malang. UB Press.

Febryan, F. (2010). The Power of Selling. Jakarta: PT Elex Media Komputindo.

Firmansyah, M. A. (2020). Komunikasi Pemasaran. Pasuruan: CV. Penerbit Qiara Media.

Gani, I. dan Amalia, S. (2015). Alat Analisis Data: Aplikasi Statistik untuk Penelitian Bidang Ekonomi dan Sosial. Yogyakarta: ANDI. 
Gunawan, C. (2020). Mahir Menguasai SPSS: Panduan Praktis Mengolah Data Penelitian. Yogyakarta: Deepublish Publisher.

Judisseno, R.K. (2017). Aktivitas dan Kompleksitas Kepariwisataan. Jakarta: PT Gramedia Pustaka Utama.

Kastolani dan Yusof, A. (2016). Relasi Islam dan Budaya Lokal: Studi Tentang Tradisi Nyadran di Desa Sumogawe Kecamatan Getasan Kabupaten Semarang. Jurnal Kontemplasi, (4) 1:51-74.

Muharto dan Ambarita, A. (2016). Metode Penelitian Sistem Informasi. Yogyakarta: Deepublish Publisher.

Purnama, I. A. (2015). Pengaruh Skema Kompensasi Denda Terhadap Kinerja Dengan Risk Preference Sebagai Variabel Moderating. Jurnal Nominal, (4)1: 129-145.

Riyanto, S. dan Hatmawan, A. A. (2020). Metode Riset Penelitian Kuantitatif: Penelitian di Bidang Manajemen, Teknik, Pendidikan dan Eksperimen. Yogyakarta: Deepublish Publisher.

Rukajat, Ajat. (2018). Pendekatan Penelitian Kuantitatif: Quantitative Research Approach. Yogyakarta: Deepublish Publisher.

Sayidah, Nur. (2018). Metodologi Penelitian: Disertai dengan Contoh Penerapannya dalam Penelitian. Sidoarjo: Zifatama Jawara.

Siregar, A.Z, dan Harahap, N. (2019). Strategi dan Teknik Penulisan Karya Tulis Ilmiah dan Publikasi. Yogyakarta: Deepublish Publisher.

Siregar, M. Y. dan Winita, (2017). Faktor-Faktor yang Mempengaruhi Volume Penjualan Sparepart pada PT Calispo Multi Utama Medan. Jurnal Akuntansi dan Bisnis: Jurnal Program Studi Akuntansi, (3)1:105-120.

Sudaryo, Y., dkk. (2019). Metode Penelitian Survei Online dengan Google Forms. Yogyakarta: Penerbit Andi.

Widayat. (2018). Statistika Multivariat:Pada Bidang Manajemen dan Bisnis. Malang: UMM Press.

Zaim, M. (2016). Evaluasi Pembelajaran Bahasa Inggris. Jakarta: Kencana. 